\title{
Elimination of Rhodnius prolixus in Central America
}

Ken Hashimoto ${ }^{1 *}$ and Christopher J Schofield ${ }^{2}$

\begin{abstract}
Rhodnius prolixus is one of the main vectors of Trypanosoma cruzi, causative agent of Chagas disease. In Central America, it was first discovered in 1915 in El Salvador, from where it spread northwest to Guatemala and Mexico, and southeast to Nicaragua and Costa Rica, arriving also in Honduras in the late 1950s. Indoor residual spraying (IRS) by the antimalaria services of Costa Rica prevented its spread southwards, and similar IRS programmes appear to have eliminated it from El Salvador by the late 1970s. In 1997, by resolution of the Ministers of Health of the seven Central American countries, a multinational initiative against Chagas disease (IPCA) was launched with one of the specific objectives being the elimination of $R$. prolixus from the region. As a result, more and more infested areas were encountered, and progressively sprayed using an IRS strategy already deployed against Triatoma infestans in the southern cone countries of South America. In 2008, Guatemala became the first of these countries to be formally certified as free of Chagas disease transmission due to $R$. prolixus. The other infested countries have since been similarly certified, and none of these has reported the presence of $R$. prolixus since June 2010. Further surveillance is required, but current evidence suggests that $R$. prolixus may now been eliminated from throughout the mesoamerican region, with a corresponding decline in the incidence of $T$. cruzi infections.
\end{abstract}

Keywords: Chagas disease, American trypanosomiasis, Rhodnius prolixus, vector control, indoor residual spraying, elimination, Central America

\section{Introduction}

By August 2011, all the previously endemic countries of Central America had been formally certified as free of Chagas disease transmission due to their main domestic vector, Rhodnius prolixus. None of these countries, nor Mexico, has reported the presence of this vector since June 2010, suggesting that $R$. prolixus may now have been completely eliminated from the mesoamerican region. This is not to say that Chagas disease itself has been eliminated, since there is not only a residue of previously infected cases, but there is also active transmission in some areas due to other vector species - especially Triatoma dimidiata. Nevertheless, the results suggest that the burden of transmission has been substantially reduced. This review summarises the background and progress of the multinational initiative against Chagas disease transmission carried out in the Central American countries (known as IPCA - Iniciativa de los Países de Centro

\footnotetext{
* Correspondence: hashimok@gmail.com

11-6-3 Miyakodai, Kamiso, Kakogawa, Hyogo 675-1215, Japan

Full list of author information is available at the end of the article
}

América para la Interrupción de la Transmisión Vectorial, Transfusional y Atención Médica de la Enfermedad de Chagas).

Information for the review has come from published scientific articles, reports of national Chagas disease control programmes, reports and presentations of annual meetings of the IPCA initiative, and personal communications. In mapping the historical distribution of $R$. prolixus (Figure 1) the location of some areas or villages was only approximate - some recent documents offer exact coordinates of infested villages, but most publications prior to the mid-1990s identified localities only by administrative departments or municipalities and for these, geographically centric points were selected.

\section{Background}

Rhodnius prolixus (Hemiptera, Reduviidae, Triatominae) is one of the most efficient vectors of Trypanosoma cruzi, the causative agent of Chagas disease. It is assumed to have evolved from the ancestral forms of other Rhodniini in or around the Amazon region of South America,
C Biomed Central

() 2012 Hashimoto and Schofield; licensee BioMed Central Ltd. This is an Open Access article distributed under the terms of the Creative Commons Attribution License (http://creativecommons.org/licenses/by/2.0), which permits unrestricted use, distribution, and reproduction in any medium, provided the original work is properly cited. 


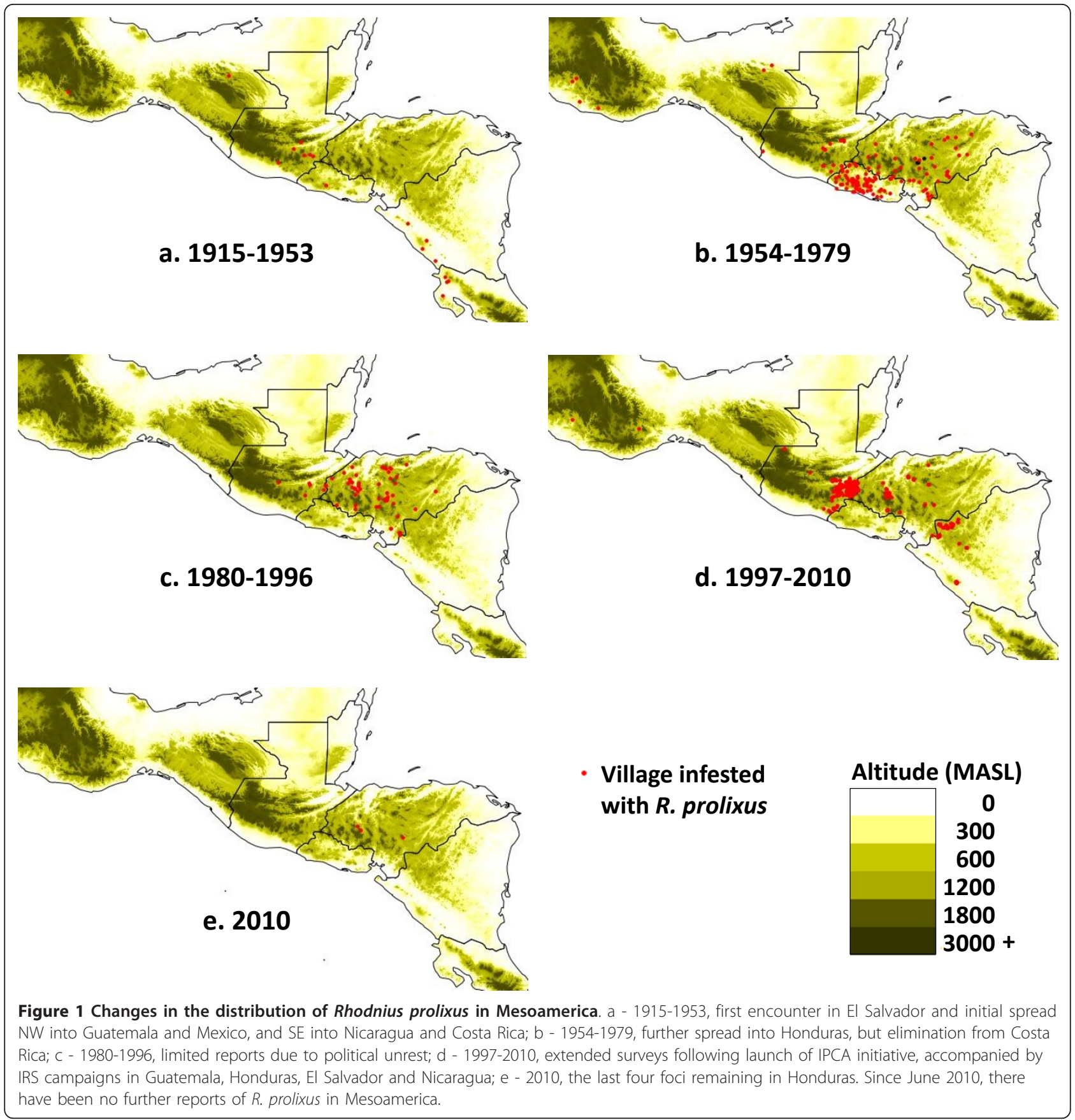

becoming highly adapted to domestic and peridomestic habitats - especially in the llanos of Venezuela and Colombia, where it remains a significant domestic vector of T. cruzi [1]. Historically however, its distribution has shown a notable discontinuity since, although widespread in parts of Venezuela and Colombia, it has never been reported from Panama nor southern or central Costa Rica $[2,3]$.

In Central America, $R$. prolixus was first reported in 1915 from the city of San Salvador [4], from where it subsequently spread in El Salvador and into Guatemala, Honduras, Nicaragua, Costa Rica, and southern Mexico. It is believed that the original specimens in San Salvador resulted from a "laboratory accident". $R$. prolixus had been collected from the region of La Guayra in Venezuela in 1912 and taken to Paris, France, for studies of its potential use in xenodiagnosis of Chagas disease (the feeding of laboratory-reared uninfected bugs on patients, and subsequent examination of the bugs' rectal contents for evidence of parasite multiplication). A sample from 
the Paris colony was then taken to San Salvador for further studies of its use in xenodiagnosis, and is assumed to have been accidentally released in 1913 [5]. In genetic terms, this scenario implies a series of founder effects and genetic bottlenecks, that would have led to the Central American form of $R$. prolixus being genetically impoverished, as indicated by its relatively small body size and reduced RAPD banding profiles [6]. One consequence is that the Central American form of $R$. prolixus seems to have been unable to colonise silvatic habitats, and appears to have remained in domestic and peridomestic habitats throughout its spread in Central America and Mexico. Nevertheless, it was able to build up very large domestic populations, with over 11,000 individuals recorded from one house in Honduras $[7,8]$, and was consistently associated with much higher rates of $T$. cruzi transmission compared to other Central American vectors such as $T$. dimidiata $[8,9]$.

\section{Distribution patterns of R. prolixus in Central America and Mexico}

The distribution of $R$. prolixus in Central America followed four main phases corresponding to its initial arrival and spread (1915-1953), early research and initial control trials (1954-1979), further research with largerscale control attempts (1979-1996), and launch of the IPCA initiative leading to its apparent elimination from the region (1997-2010) (Figure 1).

\section{5-1953: Discovery and spread}

There are no known reports of $R$. prolixus in Central America prior to 1915, when the first specimens were encountered in houses in San Salvador, the capital of El Salvador [5], now believed to have resulted from an accidental laboratory escape $[5,6]$.

From San Salvador, $R$. prolixus appears to have spread initially NW and SE, presumably due to human movements along the international Pan American highway [5], and was first reported in Guatemala in 1934 [10]. Further studies in 1943 confirmed three eastern departments of Guatemala to have house infestations with $R$. prolixus (El Progreso, Esquintla, Jalapa) along with ten departments where $T$. dimidiata was found (Alta Verapaz, Baja Verapaz, Chiquimula, El Progreso, Esquintla, Guatemala, Huehuetenango, Jalapa, Santa Rosa, Zacapa) [11]. Mexico followed in discovering the presence of $R$. prolixus in regions connected to Guatemala by the Pan American highway - in Oaxaca in 1938 [12] and Chiapas in 1949 [13]. Also in 1949, R. prolixus was first confirmed in Nicaragua [14] and by 1952 had become distributed throughout the western and central parts of the country, including the departments of Estelí, León, Masaya, Carazo, and Rivas [15]. By 1953, it was also recorded from a few houses in Guanacaste, Costa Rica, in the region bordering Nicaragua [16], but was quickly eliminated from there by insecticide spraying carried out by the antimalaria service of Costa Rica $[5,16]$.

The spread of $R$. prolixus NW and SE from San Salvador does seem to have followed the Pacific route associated with the Pan American highway, such that, for example, it has never reached the Atlantic departments of Nicaragua (RAAN: Región Autónoma del Atlántico Norte, and RAAS: Región Autónoma del Atlántico Sur), nor the Yucatan peninsula or Belize. It arrived in Honduras only during the late 1950s, possibly from neighbouring regions of Guatemala into the western departments of Copán and Santa Barbara, or from El Salvador along the Pan American highway into the southernmost department of Choluteca [17] rather than directly across the mountainous border between El Salvador and Honduras.

\section{4-1979: Early research and initial control trials}

From the 1950s, having recognised the presence of $R$. prolixus as a public health problem, the Central American countries began further investigation on its distribution and susceptibility to insecticides $[18,19]$, including field trials of possible control by indoor residual spraying (IRS) as carried out by the national malaria eradication services $[16,20]$.

In El Salvador, a nationwide control campaign against $R$. prolixus began in 1955 and continued until 1976 [20-23]. Through a series of surveys and IRS interventions, a total of 14 departments (Ahuachapán, Cabañas, Chalatenango, Cuscatlán, La Paz, La Unión, Libertad, Morazán, San Miguel, San Salvador, San Vicente, Santa Ana, Sonsonate, and Usulután) were found to be infested and all were sprayed accordingly [19-22]. In 1956, a baseline entomological survey of 23 villages of 17 municipalities in nine departments identified 14 villages with $R$. prolixus and 12 villages with $T$. dimidiata, with 326 and 244 specimens collected, respectively [20]. In a following study of 25 villages of ten municipalities in six departments during 1973-1975, 17 villages were recorded as infested with $R$. prolixus and/or T. dimidiata, noting the percentage of infested houses at $10 \%$ for $R$. prolixus and $30.3 \%$ for $T$. dimidiata [22]. The same study also recorded the number of collected specimens for $R$. prolixus and T. dimidiata as 239 and 437, respectively. Throughout El Salvador from the 1950s to 1970 s, $R$. prolixus was observed principally in houses lower than 330 MASL [21,22].

Guatemala also continued with entomological investigations during the 1950s, and by 1959 the presence of $R$. prolixus had been confirmed in the departments of Guatemala, Zacapa, Jutiapa, El Progreso, and San Mar$\cos$ [24]. In Jutiapa which shares the border with El Salvador, the number of captured specimens of $R$. prolixus was 218 , whereas that of $T$. dimidiata was just 40 . Zacapa, another eastern department bordering 
Honduras, showed a similar tendency with 309 R. prolixus captured, compared to just $31 T$. dimidiata. As in El Salvador, $R$. prolixus also seemed to predominate in houses at lower altitudes, although some were found in houses up to 1,200 MASL [24].

In Honduras, the presence of $R$. prolixus was recorded for the first time in 1960, in the departments of Santa Barbara and Francisco Morazán [17]. However, in an entomological survey conducted over 76 villages of 12 departments during 1970-72, 40 villages in nine departments (Intibucá, Copán, La Paz, Santa Barbara, Lempira, Choluteca, Olancho, Francisco Morazán, El Paraíso) were found infested with $R$. prolixus, including 14 villages with both $R$. prolixus and $T$. dimidiata (including the capital city, Tegucigalpa, where a single adult $R$. prolixus was found in a bus terminal, possibly illustrating its main mode of dispersal) [25]. The altitude of the 40 infested villages was between 460 and 1,500 MASL. This survey illustrated the rapid proliferation of $R$. prolixus in Honduras, showing a sudden rise in rural house infestations, often associated with an unexpectedly high frequency of acute Chagas infections. In 1971 for example, in a single house in Francisco Morazán, three brothers simultaneously presented with acute infections (with Romañas sign) and all eight family members proved to be serologically positive for $T$. cruzi; at that time over $600 R$. prolixus were collected from their house, with similar numbers from neighbouring houses where $50 \%$ of the inhabitants showed positive serology for Chagas disease [26]. In 1989 in this same locality (Pueblo Nuevo, Municipality of Cedros) one house was completely dismantled to give a total collection of 11,246 specimens of $R$. prolixus $[7,8]$.

In Mexico, the National Malaria Eradication Campaign began in 1956, based on residual insecticide spraying focused particularly on low-lying villages of the southernmost states [27]. These interventions included the states of Oaxaca and Chiapas, and appear to have also impacted on Chagas disease vectors [28,29]. Surveys during the 1960s and 1970s found $R$. prolixus in only four villages in Oaxaca [30-32] and two villages in Chiapas [33], and in some cases these reports were based on the finding of just a single specimen [30,32] indicating very low vector density.

\section{0-1996: Continued investigation}

Civil wars in Guatemala (1960-1996), Nicaragua (19791990), and El Salvador (1980-1992) disrupted much of the entomological research and surveillance. In Honduras however, a nationwide sampling survey was carried out during 1983-1984 [27]. This showed nine of the 14 departments to be infested with $R$. prolixus (Comayagua, Copán, Choluteca, El Paraíso, Francisco Morazán, Lempira, Olancho, Yoro, Santa Barbara) in which 17 of 27 municipalities were infested with $R$. prolixus, with almost all also showing some infestation with $T$. dimidiata. The survey also reported that neither vector was present along the Caribbean coastal areas [34].

The Honduras national survey of 1983-1984 revealed particularly high rates of house infestation and seroprevalence of $T$. cruzi in parts of the department of Choluteca. This region was then chosen by the Ministry of Health for a control trial during 1991-94, focusing on the municipalities of San Marcos de Colón and Duyure. The trial began with a baseline survey of 4,411 houses in the 288 localities of these two municipalities, of which Triatominae were found in 1,103 houses, including 634 infested with $R$. prolixus; an indoor residual spray campaign followed, covering 4,331 houses [35]. Serological studies on 3,229 children less than 5 years old showed 62 seropositives (1.9\%) who were treated with nifurtimox; serological examination 20 months later showed that $75.8 \%$ of these had become seronegative (C. Ponce, personal communication).

Guatemala restarted investigations in the early 1990s as part of a tropical disease research project with the Japan International Cooperation Agency (JICA). A national entomological survey during 1995-1997 reported $R$. prolixus in five departments (El Progreso, El Quiché, Zacapa, Chiquimula, and Jalapa), of which four are located in the east in accordance with the historical data of the 1950s [36]. Unlike previous surveys however, $R$. prolixus was now only found in villages at altitudes above 600 MASL [36].

El Salvador had suspended all vector control activities during the 1980s, but resumed after the ceasefire in 1992. In 1995, an extensive study over 14 previously endemic departments found no presence of $R$. prolixus $[37,38]$.

In Mexico, studies on vector distribution in endemic areas, as well as nationwide surveillance, continued during the 1980 s and 1990 s, but $R$. prolixus was rarely reported [e.g. $[32,39,40]]$. A detailed survey of Triatominae in the state of Oaxaca reported three specimens of $R$. prolixus collected in 1998 from two villages near a previously reported collection site at San José de las Flores [41]; this appears to be the last published record this species in Mexico, although a further specimen was collected in Oaxaca in 2002 (C. Ponce, personal communication, see also [42]).

\section{7-2010: Regional initiative and apparent elimination}

Following technical planning discussions organised by the ECLAT network (European Community Latin America Triatominae research network) [43], the Central American Chagas disease control initiative, IPCA, was launched in 1997 by resolution of the Ministers of Health of Belize, Costa Rica, El Salvador, Guatemala, Honduras, Nicaragua and Panama at their $7^{\text {th }}$ RESSCA (Reunión del Sector Salud de Centroamérica) meeting in 
Belize [38]. Having recognised Chagas disease as of major public health significance, but feasible to control according to the experiences of South American countries [e.g. $[44,45]]$, the seven countries of Central America established the objective of halting vectorial and transfusional transmission of Chagas disease, including elimination of $R$. prolixus as one of the specific means to achieve this [38]. To initiate the programme, financial aid of 500,000 US dollars was provided by the Government of Taiwan to each Central American country, although much of this was then used for emergency relief following hurricane Mitch in 1998, or for other activities, except in Nicaragua and Honduras.

Under the IPCA initiative, the essential strategy involved revisiting all localities thought to be infested from previous studies, or suspected of possible infestation due to proximity to previously-reported foci or with housing conditions considered at risk to infestation (e.g. houses with palm or thatch roofs). Houses in these localities were checked for infestation by staff of the ETV programmes (Enfermedades Transmitidas por Vectores/Vector-borne Diseases) and/or trained community volunteers, by consultation with the householders and a physical search of the premises for the presence of Triatominae. On initial inspection, the finding of a single live $R$. prolixus in any house was sufficient to declare the whole locality infested, and organise indoor residual spraying (IRS) of all houses and peridomestic habitats in the locality, usually using a $3^{\text {rd }}$ generation pyrethroid such as deltamethrin $\mathrm{SC}$ at $25 \mathrm{mg}$ a.i. $/ \mathrm{m}^{2}$, or lambdacyhalothrin WP at $30 \mathrm{mg}$ a.i. $/ \mathrm{m}^{2}$, following WHO guidelines [46-48]. Subsequently, if a house were again found to be infested through follow-up inspections or community-based surveillance, all houses in the village were resprayed.

Nicaragua was the first country to implement the programme, conducting entomological surveys in 19981999, IRS campaigns in 1999-2002, and follow-up surveillance with focal spraying during 2002-2009 [49]. The initial surveys covered 32,195 houses in 129 municipalities of all departments (except RAAN and RAAS where $R$. prolixus had never been reported), revealing the presence of $R$. prolixus in 59 villages of 14 municipalities in eight departments (Carazo, Chinandega, Granada, Jinotega, Madriz, Masaya, Matagalpa, and Nueva Segovia) [49]. The 59 infested villages were at altitudes between 60 and 1,414 MASL, with 8 of these (13.6\%) below 600 MASL [49]. By 2002, it appeared that all these infestations had been eliminated by an IRS campaign, but extended surveys during 2002-2004 revealed three further infested localities in the departments of Madriz, Nueva Segovia, and Matagalpa [50]. These newly-discovered infested villages were sprayed during 2007-2008, but again, the subsequent entomological surveillance showed $R$. prolixus in four more villages in Madriz and Nueva Segovia [51]. In 2009, $R$. prolixus was found in one village in Madriz, and this seems to be the last report of this species in Nicaragua [49].

In 1998, Honduras also initiated vector control activities in a few endemic areas of the departments of Santa Barbara and Francisco Morazán. Discovery of villages infested with R. prolixus augmented during 1999-2002, when MSF (Médecins sans Frontières) implemented Chagas disease control projects in the departments of Yoro and Francisco Morazán, finding R. prolixus in 116 villages in Yoro and 60 villages in Francisco Morazán $[52,53]$. Alongside the MSF projects, the Honduran Ministry of Health continued finding foci of $R$. prolixus in the departments of Olancho (30 villages), El Paraíso (12 villages), La Paz (5 villages), Choluteca (2 villages), Intibucá ( 1 village) and Copán (1 village), all of which share borders with Nicaragua, El Salvador or Guatemala.

El Salvador continued with an entomological survey over 162 villages of 14 departments during 1999-2000 [7] and implemented a vector control project with JICA, directed primarily against $T$. dimidiata, that covered seven departments (Ahuachapán, Libertad, Morazán, San Miguel, Santa Ana, Sonsonate, and Usulután) during 2003-2011. A further entomological study covering all 43 municipalities bordering Guatemala or Honduras, searched for possible infestation by $R$. prolixus, but no specimens of this vector were found throughout these surveys [23].

Guatemala carried out vector control projects with JICA through the periods of 2000-2007 and 2009-2012. During these, a total of 317 villages of nine departments reported the presence of $R$. prolixus. The number of infested villages was 230 in Chiquimula, 35 in Zacapa, 29 in Jalapa, 10 in Jutiapa, 8 in El Progreso, 2 in Huehuetenango, 1 in Santa Rosa, 1 in Baja Verapaz, and 1 in El Quiché. Of the 317 villages, 313 (98.7\%) were located in the eastern region of the country (mainly bordering Honduras).

During 2003 to 2011, Honduras also intensified vector control interventions with international aid from JICA, CIDA (Canadian International Development Agency), World Vision, and CARE International $[54,55]$. The number of villages with $R$. prolixus registered during this period reached 70 in Intibucá, 47 in La Paz, 30 in Olancho, 27 in Lempira, 24 in Copán, 19 in Yoro, 8 in Francisco Morazán, 7 in Santa Barbara, 6 in Ocotepeque, 6 in Comayagua, and 4 in El Paraíso. Among the total of 228 villages found infested during 2003-2011, 20 appeared to have been reinfested since control attempts in 2003.

Following the intensified IRS and surveillance campaigns, in 2008 Guatemala became the first country to be certified by IPCA as having interrupted transmission 
of Chagas disease due to $R$. prolixus. And having evidenced significant reduction in vector distribution and in seroprevalence in children in endemic areas, Nicaragua and Honduras were similarly certified in 2011. Also, because of the apparent absence of $R$. prolixus following repeated surveys and continual surveillance, certification of elimination of this vector was awarded to Mexico in 2009, El Salvador in 2010 and Costa Rica in 2011. In 2010, Honduras was the only country in Central America to report the presence of $R$. prolixus with four infested villages (Figure 1e) and by June of that year these four localities had been resprayed [55]. Since then, there have been no further reports of $R$. prolixus in Central America, and it may be that regional elimination has been achieved (Table 1).

\section{Discussion}

The discontinuous distribution of $R$. prolixus between the llanos of Venezuela and Colombia, and various parts of Central America, has long invited speculation. The two forms are genetically similar [6] and in both areas appear to have been of domestic and peridomestic habit, associated particularly, but not exclusively, with houses of palm-thatch roofs. The absence of $R$. prolixus from NW Colombia, Panama, and southern and central Costa Rica, suggests that active migration between the South and Central American populations was not possible, and that passive transport, for example amongst the belongings of travellers, was limited by the difficult access through the Darian region of the isthmus. Gamboa [56,57], on first finding Rhodnius populations in palmtree crowns in Venezuela, suggested that the discontinuity might be explained by passive transport of eggs and nymphs by birds (Mycteria americana) migrating between Venezuela and Central America but, although often repeated, there is no further evidence to support this idea. The Venezuelan palmtree populations of Rhodnius were almost certainly the morphologically similar $R$. robustus (from which the domestic $R$, prolixus may have derived [1]) and, in spite of numerous studies, no populations of Rhodnius have been found in Central American palmtree crowns (except for the distinctive $R$. pallescens in Panama, Costa Rica, and parts of Nicaragua).

If the Central American forms of $R$. prolixus originated from an accidental escape from a laboratoryreared colony at the beginning of the last century, then these forms have shown a remarkable capacity for dispersal. Within half a century they reached five countries [2] and we may suppose that, were it not for interventions by the antimalaria services of Costa Rica and Mexico, they may have spread even further. They showed no apparent capacity for colonising silvatic habitats, but readily colonised rural houses and peridomestic habitats, especially those with roofs of palm or thatch, in some cases reaching very high density populations. But unlike the spread of Triatoma infestans in Central Brazil during the same period, which seems to have displaced previous domestic infestations of Panstrongylus megistus $[44,45]$, there is no evidence that Central American $R$. prolixus were displacing previous infestations of autochthonous Triatominae, and this may have contributed to their apparent ease of domestic dispersal. They appear to have followed the main routes of human migration along the Pacific side of Central America, presumably carried amongst the belongings of travellers and migrant workers. So up to the 1970s, they were mainly found in the more densely populated lowland areas (below $600 \mathrm{MASL}$ ) and, since the 1950s, these lowland regions became the main focus for antimalaria interventions by indoor residual spraying (IRS) that appear to have had a substantial impact.

The apparent success of the vector control interventions against $R$. prolixus in Central America thus seems to have been influenced by both biological and operational factors. The history of its accidental release into

Table 1 The rise and fall of Rhodnius prolixus in Central America and Mexico.

\begin{tabular}{|c|c|c|c|c|}
\hline & \multirow[t]{2}{*}{ First reported presence } & \multirow[t]{2}{*}{ Last reported presence } & \multicolumn{2}{|c|}{ PAHO-IPCA certification } \\
\hline & & & * & $* *$ \\
\hline El Salvador & 1915 & 1976 & & 2010 \\
\hline Guatemala & 1934 & 2008 & 2008 & $(1)$ \\
\hline Mexico & 1938 & 2002 & & 2009 \\
\hline Nicaragua & 1949 & 2009 & 2011 & $(2)$ \\
\hline Costa Rica & 1952 & 1953 & & 2011 \\
\hline Honduras & 1960 & 2010 & 2011 & $(2)$ \\
\hline Belize & never encountered & & & \\
\hline Panama & never encountered & & & \\
\hline
\end{tabular}

* formal certification of interruption of transmission of Trypanosoma cruzi due to Rhodnius prolixus** formal certification of elimination of Rhodnius prolixus (1)Guatemala has now completed three years with no reports nor encounters of $R$. prolixus in surveys, and is being considered for formal certification of elimination of this species.(2)Nicaragua and Honduras have now completed almost two years with no reports nor encounters of $R$. prolixus in surveys, and may be considered for certification of elimination if this continues. 
the region [5], largely confirmed by genetic comparisons [6], suggests that the Central American populations had experienced a series of founder effects and genetic bottlenecks - the original sample collected in Venezuela and reared in Paris, the subsample then taken to El Salvador, and successive subsamples assumed to have been accidentally carried to other countries in association with human migrations, leading to a genetically restricted form showing relatively low variability [6] and hence low likelihood of selection for new attributes such as insecticide resistance. These Central American populations then showed high susceptibility to insecticides, particularly to pyrethroids [58,59], and it seems likely that antimalarial IRS campaigns launched during the 1950s-60s would have contributed significantly to their control. Even the widespread use of DDT during the antimalaria campaigns could have contributed, because although DDT is generally considered ineffective against Triatoma [60] it has been shown to have at least a latent effect against $R$. prolixus in Venezuela [61], and seems likely to have had a more significant effect on the smaller and genetically-restricted Central American forms of this species. This idea is reinforced by the initial disappearance of $R$. prolixus from the lower altitude villages, where antimalaria campaigns were most intense, and also by its apparent disappearance from Mexico where there have been few control campaigns specifically directed against Triatominae.

In Central America, despite numerous studies, $R$. prolixus was never encountered in silvatic habitats, and appears to have been confined to domestic and peridomestic habitats, especially houses with roofs of palm or thatch. In addition to the insecticide spraying, it seems likely that house improvement may have contributed to reducing the vector distribution. Especially over the last two decades, thatched roofs have tended to be replaced with roofs of tile or corrugated metal - although $R$. prolixus has been found in the walls of tin roofed houses in Honduras and Guatemala [54], and it has been demonstrated that house improvement alone is generally insufficient to eliminate domestic populations of Triatominae [e.g. [62]].

But the key factors in the successful control of $R$. prolixus in Central America have been the technical recognition of its importance as a public health problem and the feasibility of its successful control [43] followed by commitment of the National Governments, together with technical and financial support from other agencies. Initial commitment by researchers led to the discovery of $R$. prolixus and documentation of the potential magnitude of Chagas disease as a public health issue. This alert was responded to by the Salvadoran and Costa Rican governments by investing in vector control operations that had a substantial impact during the
1950 s-1970s. From the 1980 s to early 1990 s however, the government commitment to Chagas disease control was negligible in Guatemala, Nicaragua and El Salvador, mainly due to the political unrest. The Ministry of Health of Honduras continued with serological and entomological studies, mostly with external funds, and provided important data that helped to vitalise interest in a regional Chagas disease control programme. In the early 1990s, the Guatemalan national university restarted entomological survey work with financial and technical assistance from JICA, such that these two centres; the $\mathrm{MoH}$ of Honduras, and the Universities of Guatemala, became the main technical centres supporting the regional control efforts (See acknowledgements).

Establishment of IPCA in 1997 was a turning point, backed by scientific consensus [43], political commitment with coordination from the Pan American Health Organization [38], and supported by international organizations (JICA, CIDA) and NGOs (MSF, CARE, PLAN and World Vision). As pledged by the member countries, the focus of commitment was altered from investigation to operational interventions designed to achieve the specific objectives, including elimination of $R$. prolixus. The clear objectives of the IPCA programme facilitated the mobilisation of additional national resources, and also promoted participation of international donors with operational, managerial, technical and financial assistance. Involvement of the external stakeholders further contributed to raise the priority level of Chagas disease control within the Ministries of Health, improving resource allocation and gradually integrating the activities into existing programmes of epidemiological surveillance and vector control. Through support from the ECLAT network and PAHO, much was learned from the experience of other countries, especially in relation to the control of Triatoma infestans in the southern cone countries [e.g. [43-45]], and the IPCA annual meetings and thematic workshops also paved the way for definition of criteria for certification of interruption and elimination of Chagas disease transmission [e.g. [7]]. To a certain extent, the IPCA workshops also encouraged competition in achieving the objectives, through open discussion of the annual achievements of each of the national programmes.

Although it now appears that by the mid-1990s the overall distribution of $R$. prolixus in Central America had been reduced by antimalaria IRS interventions, especially in El Salvador, Costa Rica, and Mexico, and may also have been declining in some areas through local house improvement, it remained the most significant vector of Chagas disease throughout the region [7-9]. In 1990, it was estimated from serological surveys that over 1.77 million people were infected with $T$. cruzi in Central America, implying an overall incidence of 
nearly 62,000 new cases per year [63]. But by 2006 , following the main vector control campaigns, estimates by the Pan American Health Organization suggested that infection prevalence in the region had declined to 806,000 , with just 8,500 new cases per year attributable to vector-borne transmission (mainly due to residual infestations with $T$. dimidiata) $[64,65]$. With the apparent elimination of $R$. prolixus, these estimates can be expected to decline further.

\section{Conclusion}

R. prolixus appears to have been accidentally released into Central America early in the last century, and spread rapidly to become the most serious vector of Chagas disease in the mesoamerican region. Since the 1950 s, indoor residual spray campaigns by the malaria eradication services appear to have halted its spread, and reduced its distribution in lowland areas, but most interventions were suspended during the civil unrest of the 1980s. In 1997, the Central American countries launched a multinational initiative against Chagas disease (IPCA) that included elimination of $R$. prolixus amongst the main objectives. The clear objectives and strong political mandate attracted external support (especially from the Japanese Cooperation, JICA) and facilitated operational planning and implementation of large-scale vector surveillance and control interventions. By August 2011 all the previously endemic countries of Central America had been certified as free of Chagas disease transmission due to $R$. prolixus, and it may be that this vector has now been eliminated from the mesoamerican region.

\section{List of Abbreviation}

CIDA: Canadian International Development Agency; ECLAT: European Community Latin America Triatominae research network; ETV: Enfermedades Transmitidas por Vectores; IPCA: Iniciativa de los Países de Centro América para la Interrupción de la Transmisión Vectorial, Transfusional y Atención Médica de la Enfermedad de Chagas; IRS: Indoor residual spraying; JICA: Japan International Cooperation Agency; MASL: Meters above Sea Level; MSF: Médecins sans Frontières; PAHO: Pan American Health Organization; RAAN: Region Autónoma del Atlántico Norte (North Atlantic Autonomous Region of Nicaragua); RAAS: Región Autónoma del Atlántico Sur (South Atlantic Autonomous Region of Nicaragua); RAPD: Random Amplification of Polymorphic DNA; RESSCA: Reunión del Sector Salud de Centroamérica.

\section{Acknowledgements}

This review is dedicated to all those who maintained interest and gathered crucial data even during the difficult times prior to the IPCA initiative, especially Carlos and Elisa Ponce, formerly of the Central Reference Laboratory of the Ministry of Health of Honduras, Rafael Cedillos of the University of El Salvador, and Carlota Monroy and Celia Cordón-Rosales of the National University and University del Valle, respectively, of Guatemala. The initial idea that $R$. prolixus was an accidental introduction to Centra America (and hence candidate for elimination) can be attributed to Rodrigo Zeledón of the University Heredia, Costa Rica (see ref. 43). This review benefited from international collaboration through the ECLAT network, $\mathrm{PAHO}$, and JICA.

\section{Author details}

11-6-3 Miyakodai, Kamiso, Kakogawa, Hyogo 675-1215, Japan. ${ }^{2}$ Department of Infectious and Tropical Diseases, London School of Hygiene and Tropical Medicine, London WC1 E7HT, UK.

\section{Authors' contributions}

$\mathrm{KH}$ and CJS conceived the review design, wrote the drafts and approved the final manuscript.

\section{Competing interests}

The authors declare that they have no competing interests.

Received: 27 January 2012 Accepted: 22 February 2012

Published: 22 February 2012

\section{References}

1. Schofield CJ, Galvão C: Classification, evolution and species groups within the Triatominae. Acta Trop 2009, 110:88-100.

2. Dias E: Doenca de Chagas nas Americas. Rev Malariol Doencas Trop 1953, 5:11-16.

3. Schofield CJ: American trypanosomiasis. Geographical distribution of arthropod-borne diseases and their principal vectors World Health Organization manual 1989, WHONBC/89.967;81-92

4. Neiva A: Contribuição para o conhecimento dos hemípteros hematophagos de America Central. Brasil Médico 1915, 29:1-3.

5. Zeledón R: Some historical facts and recent issues related to the presence of Rhodnius prolixus (STAL, 1859) (HEMIPTERA: REDUVIIDAE) in Central America. Entomol Vect 2004, 11:233-246.

6. Dujardin JP, Muñoz M, Chavez T, Ponce C, Moreno J, Schofield CJ: The origin of Rhodnius prolixus in Central America. Med Vet Entomol 1998, 12:113-115.

7. Pan American Health Organization: Informe Final; Reunión Internacional para el Establecimiento de Criterios de Certificación de la Eliminación de Rhodnius prolixus. La comisión intergubernamental de la Iniciativa de los Países de Centro América (IPCA) para la interrupción de la trasmisión vectorial y transfusional de la enfermedad de Chagas. Guatemala, 5-7 Marzo 2003, OPS/DPC/CD/276/03.

8. Ponce $\mathrm{C}$, Ponce $\mathrm{E}$, Flores M, Avila G: Intervention trials of new tools to control transmission of Chagas disease in Honduras. Mem Inst Oswaldo Cruz 1993, 12:57-58.

9. Paz-Baily G, Monroy C, Rodas A, Rosales R, Tabaru Y, Davies C, Lines J: Incidence of Trypanosoma cruzi infection in two Guatemalan communities. Trans R Soc Trop Med Hyg 2002, 96:48-52.

10. De León R: La Trypanosomiasis Americana o Enfermedad de Chagas en Guatemala. Gaceta Médica Centroamericana 1943, Tomo I(2):57-60.

11. Montenegro ML: Consideraciones sobre la Tripanosomiasis Americana o Enfermedad de Chagas en Guatemala. Guatemala: Facultad de Ciencias Médicas de la Universidad Nacional; 1943.

12. Mazzoti L: Triatomídeos de México y su infección de Trypanosoma cruzi Chagas. Medicina 1940, 20(358):95-109.

13. Mazzotti L, Dias E: Resumen de los datos publicados sobre la Enfermedad de Chagas en Mexico. Rev Soc Mex Hist Nat 1949, 10:103-111.

14. Alvarez-Montalbán E, Gutiérrez RA: Sobre un caso de enfermedad de Chagas. Nicaragua Med 1949, 5:258-268.

15. Zeledón R: El problema de la tripanosomiasis o enfermedad de Chagas en Costa Rica. Thesis Ministerio de Salubridad Pública, Investigaciones Epidemiológicas No 2; 1952.

16. Ruiz H: Rhodnius prolixus en Costa Rica. Rev Biol Trop 1953, 1:239-240.

17. León-Gómez A, Flores-Fiallos A, Reyes-Quesada L, Poujol ER, Bonilla MR, Gómez-Padilla C: La enfermedad de Chagas en Honduras. Rev Med Hondureña 1960, 28:78-83. 
18. Peñalver LM, Rodríguez MI, Sancho G: Trypanosomiasis Humana en El Salvador - Reporte Preliminar. Archivos de Colegio Médico de El Salvador 1956, 9(3):167-184

19. Peñalver LM, Villagran E: Experimentos con el insecticida dieldrin en la lucha antitriatomidea. Bol Of Sanit Panam 1955, 38(2):127-140.

20. Peñalver LM, Rodríguez MI, Bloch M, Sancho G: Trypanosomiasis Humana en El Salvador. Reporte preliminar. Arch Col Médico de El Salvador 1956. 9(3):167-184

21. Cedillos RA: La enfermedad de Chagas en El Salvador. Bol Ofic Sanit Panam 1975, 78(5):430-438.

22. Wilton DP, Cedillos RA: Los triatomineos domesticos (reduvidos) y las infecciones tripanosomicas en insectos en El Salvador. Bol Ofic Sanit Panam 1979, 86(2):430-438

23. Organización Panamericana de la Salud: La Enfermedad de Chagas en El Salvador Evolución Histórica y Desafíos para el Control. San Salvador; 2010.

24. Ministerio de Salud Pública y Asistencia Social: Homenaje al cincuentenario del descubrimiento de la enfermedad de Chagas (Trypanosomiasis Americana) 1909-1959. Guatemala 1959.

25. Ponce C, Zeledón R: La enfermedad de Chagas en Honduras. Bol Of San Panam 1973, 75:239-248.

26. Ponce $\mathrm{C}$, Trochez $\mathrm{H}$, Zeledón R: Observaciones sobre enfermedad de Chagas y tripanosomiasis rangeli en tres ranchos del Departamento Francisco Morazán, Honduras. Rev Biol Trop 1974, 22:289-303.

27. Marcos Cueto FM: Cold war, deadly fevers: malaria eradication in Mexico, 1955-1975 Washington, D.C.: Woodrow Wilson Center Press; 2007.

28. Secretaría de Salud: Programa de Acción: Enfermedades Transmitidas por Vector México, D.F.: Secretaría de Salud; 2001 [http://www.salud.gob.mx/ unidades/cdi/documentos/vectores.pdf]

29. Goldsmith RS, Zárate RJ, Zárate LG, Kagan I, Jacobson LB, Morales G: Estudios clínicos y epidemiológicos de la enfermedad de Chagas en Oaxaca, México, y un estudio complementario de siete años. 1. Cerro del Aire. Bol Oficina Sanit Panam 1986, 2:100.

30. Tay J, Goycolea O, Biagi FF: Observaciones sobre enfermedad de Chagas en la Mixteca Baja, nuevo caso humano en la República Mexicana. Bol Oficina Sanit Panam 1961, 51:322-7.

31. Biagi F, Navarrete F: Estado actual de nuestros cono- cimientos sobre la enfermedad de Chagas en México I. Transmisores. Ann Congr Int Doença de Chagas 1960, 1:285-289.

32. Goldsmith RS, Kagan IG, Zarate R, Reyes-Gonzales MA, Cedeno Ferreira J: Epidemiologic studies of Chagas disease in Oaxaca, Mexico. Bull Pan Am Health Organ 1978, 12(3):236-250.

33. Ortega M, Beltran P, Zavala J: Enfermedad de Chagas en Chiapas. Estudios clinicoepidemiológicos. Salud Pub Mex 1976, 18:837-843.

34. Ponce C: Informe Final: Estudio de prevalencia de la enfermedad de Chagas en Honduras. Honduras: Secretaría de Salud 1986.

35. Tabaru Y, Monroy C, Rodas A, Mejia M, Rosales R: The geographic distribution of vectors of Chagas disease and population at risk of infection in Guatemala. Med Entomol Zool 1999, 50:9-17.

36. Ministerio de Salud de Honduras: Informe de la Región de Salud N4 Honduras: Ministerio de Salud de Honduras; 1993.

37. Ministerio de Salud Pública y Asistencia Social: Indices de infestación de triatominos en los 14 departamentos geográficos de El Salvador, Centro América San Salvador: Ministerio de Salud Pública y Asistencia Social; 1997.

38. World Health Organisation: Informe final: Reunión sobre Vectores de la Enfermedad de Chagas en los Países de Centroamérica: 22-24 October 1997; Tegucigalpa, Honduras. World Health Organisation; 1997.

39. Salazar PM, Bucio MI, De Haro I, Tay J, Alonzo T: Reservorios y trasmisores de Trypanosoma cruzi de el estado de Oaxaca. Salud Pub Mex 1987, 29(1):26-32

40. Vidal-Acosta V, Ibáñez-Bernal S, Martínez-Campos C: Infección natural de chinches Triatominae con Trypanosoma cruzi asociadas a la vivienda humana en México. Salud Pub Mex 2000, 42:496-03.

41. Ramsey JM, Ordoñez R, Cruz-Celis A, Alvear AL, Chavez V, Lopez R, Pintor JR, Gama F, Carrillo S: Distribution of domestic Triatominae and stratification of Chagas disease transmission in Oaxaca, Mexico. Med Vet Entomol 2000, 14:19-30.

42. Organización Panamericana de la Salud: Seminario "Situación de Rhodnius prolixus en México al año 2009" México DF 18 noviembre 2009 Montevideo, informal Organización Panamericana de la Salud publication; 2009.
43. Schofield CJ, Dujardin JP, Jurberg J: Proceedings of the International Workshop on Population Genetics and Control of Triatominae, Santo Domingo de los Colorados, Ecuador. Mexico City: INDRE 1996.

44. Schofield CJ, Dias JCP: The Southern Cone Initiative against Chagas Disease. Adv Parasitol 1999, 42:1-27.

45. Dias JCP, Silveira AC, Schofield CJ: The Impact of Chagas Disease Control in Latina America - A Review. Mem Inst Oswaldo Cruz 2002, 97(5):603-612.

46. Schofield CJ: Field Testing and Evaluation of Insecticides for Indoor Residual spraying against domestic vectors of Chagas Disease. WHO/ CDS/WHOPES/GCDPP/2001.1 Geneva: World Health Organisation; 2001, 54 [http://whqlibdoc.who.int/hq/2001/WHO_CDS_WHOPES_GCDPP_2001.1.pdf].

47. Schofield CJ: Pruebas de Campo y Evaluación de Insecticidas para rociado residual contra vectores domesticas de la Enfermedad de Chagas. OPS-JICA (translation of english original) 2006, 43.

48. Schofield CJ: Challenges of Chagas Disease Vector Control in Central America. WHO/CDS/WHOPES/GCDPP/2000.1 Geneva: World Health Organisation; 2000, 36[http://whqlibdoc.who.int/hq/2000/ WHO_CDS_WHOPES_GCDPP_2000.1.pdf].

49. Yoshioka K, Tercero D, Pérez B, Lugo E: Rhodnius prolixus en Nicaragua: distribución geográfica, control y vigilancia entre 1998 y 2009. Rev Panam Salud Publica 2011, 30(5):439-444.

50. Marín F: Control de Rhodnius prolixus en Nicaragua. Informe final Reunión Internacional para el Establecimiento de Criterios de Certificación de la Eliminación de Rhodnius prolixus. OPS/DPC/CD/276/03 Guatemala: Organización Panamericana de la Salud; 2003, 17.

51. MINSA/OPS/AECl: Informe final - Plan de acción operativo para el control de la Enfermedad de Chagas en 3 SILAIS endémicos de Nicaragua. Managua: Ministerio de Salud de Nicaragua, Organización Panamericana de la Salud, Agencia Española de Cooperación Internacional; 2008.

52. Médecins Sans Frontières: Informe Final - Proyecto de Apoyo a la Enfermedad de Chagas, Francisco Morazán, Honduras, 1999-2002. Tegucigalpa 2002.

53. Médecins Sans Frontières: Informe Final - Proyecto de Apoyo a la Enfermedad de Chagas, Yoro, Honduras, 1999-2002. Tegucigalpa 2002.

54. Secretaría de Salud, Japan International Cooperation Agency: Informe Final - Proyecto de Control de la Enfermedad de Chagas (2003-2007). Tegucigalpa 2007.

55. Secretaría de Salud, Japan International Cooperation Agency: Informe Final - Proyecto de Control de la Enfermedad de Chagas Fase 2 (2008-2011). Tegucigalpa 2011.

56. Gamboa CJ: In Dispersión de Rhodnius prolixus en Venezuela. Volume 3. Boletin Informativo de la Direccion de Malariologia y Saneamiento Ambiental; 1962:262-272

57. Gamboa CJ: Comprobación de Rhodnius prolixus extradomiciliario en Venezuela (comunicación preliminar). Bol Oficina Sanit Panam 1963, 54:18-25.

58. Tabaru Y, Monroy C, Rodas A, Mejia M, Rosales R: Chemical control of Triatoma dimidiata and Rhodnius prolixus (Reduviidae: Triatominae), the principal vectors of Chagas disease in Guatemala. Med Entomol Zool 1998, 49:87-92.

59. Nakagawa J, Cordón-Rosales C, Juárez J, Itzep C, Nonami T: Impact of residual spraying on Rhodnius prolixus and Triatoma dimidiata in the department of Zacapa in Guatemala. Mem Inst Oswaldo Cruz 2003, 94:417-418.

60. Schofield $\mathrm{CJ}$ : Critical review of the status of resistance to pesticides in Triatominae, and the methods for its detection. Working paper - WHO Expert Committee on Insecticide Resistance, 5-18 March, 1991 mimeographed document no. CTD/OPR/EC/91.26. Geneva: World Health Organization; 1991.

61. Nelson MJ, Colmenares P: Topical application of insecticides to Rhodnius prolixus (Hemiptera, Reduviidae) a Chagas disease vector. WHONBC/ 79.737 World Health Organization; 1979.

62. Guillen G, Diaz R, Jemio A, Cassab JA, Pinto CT, Schofield CJ: Chagas disease vector control in Tupiza, southern Bolivia. Mem Inst Oswaldo Cruz 1997, 92(1):1-8.

63. World Health Organization: Control of Chagas disease Technical Report series no.811. Geneva: World Health Organisation; 1991.

64. Organización Panamericana de la Salud: Estimación cuantitativa de la Enfermedad de Chagas en las Americas OPS/HDM/CD/425-06. Organización Panamericana de la Salud; 2006. 
65. Organización Panamericana de la Salud: Reunion técnica en materia de control vectorial; nuevos hitos y propuestas para el control de Triatoma dimidiata (Latreille, 1811) en Centroamerica. OPS/HSD/CD/006-11. Organización Panamericana de la Salud 2011.

doi:10.1186/1756-3305-5-45

Cite this article as: Hashimoto and Schofield: Elimination of Rhodnius prolixus in Central America. Parasites \& Vectors 2012 5:45.

Submit your next manuscript to BioMed Central and take full advantage of:

- Convenient online submission

- Thorough peer review

- No space constraints or color figure charges

- Immediate publication on acceptance

- Inclusion in PubMed, CAS, Scopus and Google Scholar

- Research which is freely available for redistribution

Submit your manuscript at www.biomedcentral.com/submit
() Biomed Central 